\title{
CONSUMPTION OF PEDUNCULATE OAK (QUERCUS ROBUR L.) SEEDS
}

\author{
Helga Migaskó and Károly Ecseri ${ }^{1}$ \\ Department of Horticulture, Faculty of Horticulture and Rural Development, John von Neumann University, \\ Hungary \\ https://doi.org/10.47833/2020.1.AGR.001
}

\begin{tabular}{|c|}
\hline $\begin{array}{l}\text { Keywords: } \\
\text { sensory testing } \\
\text { tannin content } \\
\text { functional food } \\
\text { bitter taste } \\
\text { oak acorn }\end{array}$ \\
\hline Article history: \\
\hline Received 6 Sep 2019 \\
\hline $20 \operatorname{Sep} 2019$ \\
\hline Accepted $\quad 25$ Sep 2019 \\
\hline
\end{tabular}

\begin{abstract}
Sensory testing of acorn flour of pedunculate oak was carried out, which is significant forest species in Europe. Dark chocolate was mixed in different proportions to the pastry, and the baked biscuits were tasted. The critics found the $50 \%$ chocolate content treatment to the best in each of tested parameters (color, odor, hardness, moisture, after taste). There was no statistical difference in the gender, age and educational level of the tasters. The experiment should be continued because of the successful reduction of bitter aftertaste.
\end{abstract}

\section{Introduction}

The plant parts on the forests and fields were collected and consumed by our ancestors not only in famine times. They also used forest component species, such as Quercus robur $L$. [2]. This activity has declined significantly in Hungary, but traditional, natural and healthy foods have a renaissance nowadays. Valuable content (unsaturated fatty acids, carbohydrates, amino acids) is reported in the case of pedunculate oak acorns in professional literature [5]. The tannin content is the only barrier to the spread of acorn flour products from which bakery products will be bitter [1]. The aim of our research is to reduce this unpleasant taste effect and to enhance the organoleptic value.

\section{Material and Methods}

The nuts were harvested from Quercus robur trees of the Great Hungarian Plain in October 2018. After drying and peeling, the seeds were ground to flour by a crop mill. The classic shortbread recipe ( 3 parts flour -2 parts butter -1 part sugar) was used for pastry making. Dark chocolate was used to reduce the bitter taste.

Applied treatments were:

A: 1 part chocolate -5 parts pastry,

B: 1 part chocolate -4 parts pastry,

C: 1 part chocolate -3 parts pastry,

D: 1 part chocolate -2 parts pastry,

E: 1 part chocolate -1 part pastry.

These biscuits were baked in preheated oven for 20 minutes and offered to the critics for tasting. Five parameters had to be evaluated on the sheet for all treatments by 44 food taster. The value of five means 'neutral' for each parameter (Table 1). In addition, we asked three sociological data (gender, age, educational level) from the respondents. Distribution of these categories was:

21 females and 23 males;

- 11 tasters 11-20 years, 17 tasters 21-30 years, 4 tasters 31-40 years, 1 taster 41-50 years, 7 tasters $51-60$ years, 3 tasters $61-70$ years and 1 taster $71-80$ years old;

- 1 taster primary, 28 tasters secondary and 15 tasters higher educated (college/university).

\footnotetext{
${ }^{1}$ Corresponding author. E-mail address: ecseri.karoly@kvk.uni-neumann.hu
} 
The relationship between the data was analyzed by Pearson's correlation analysis, and then the effect of the treatment was evaluated by univariate or multivariate analysis of variance. The pairwise comparison was based on the Tukey test. SPSS 20 was used for statistical analysis.

Table 1. Evaluation sheet

\begin{tabular}{|c|c|c|c|c|c|}
\hline Parameters & $A$ & $B$ & $C$ & $D$ & $E$ \\
\hline Color (1-dark, 9-bright) & & & & & \\
\hline Odor (1-unpleasant, 9-pleasant) & & & & & \\
\hline Hardness (1-hard, 9-soft, friable) & & & & & \\
\hline Moisture (1-dry, 9-oily, wet) & & & & & \\
\hline After taste (1-bitter, 9-no bitter) & & & & & \\
\hline
\end{tabular}

\section{Results}

Significant differences could be detected when evaluating the sheets of 44 food taster. The color of the moderately flavored $A$ and $B$ treatments received near neutral score, then the color of the biscuits constantly become darker based on the opinion of the tasters (Figure 1).

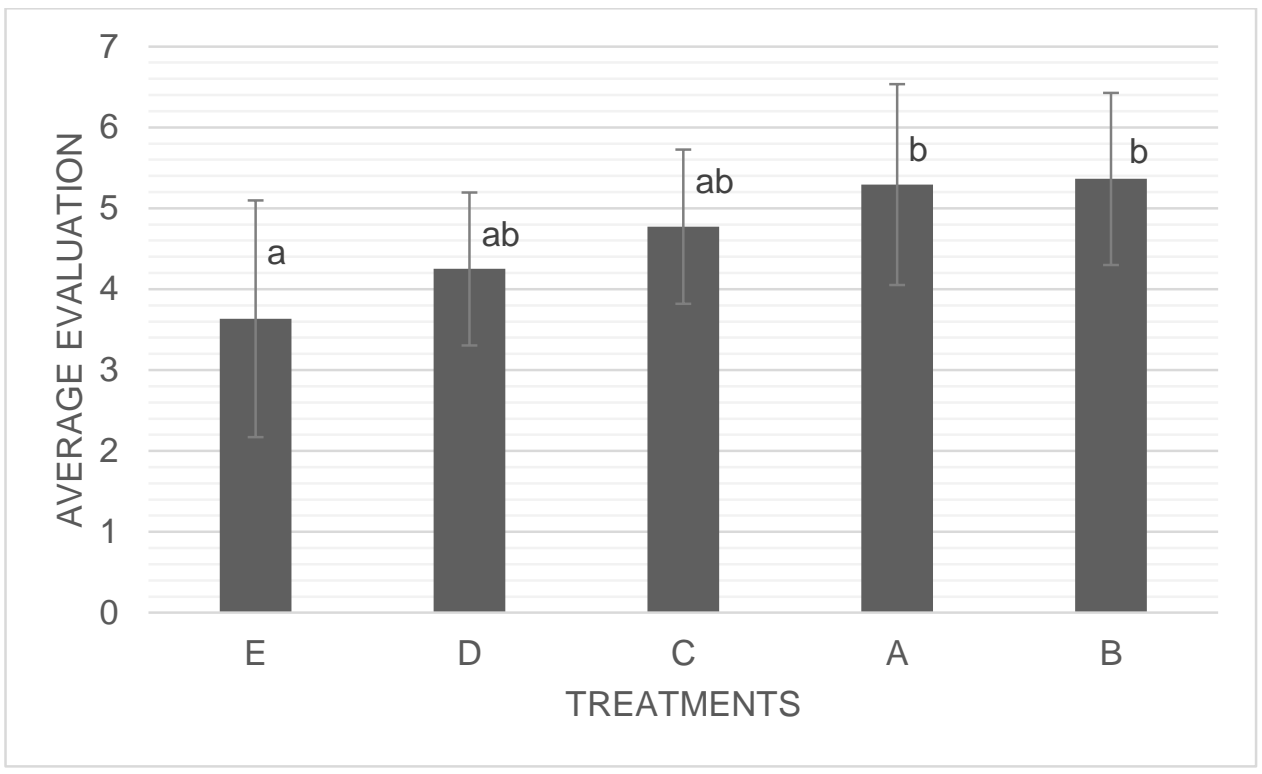

Figure 1. Evaluation the color of biscuits made from oak acorn meal

There was a significant difference between the highest chocolate content $(E)$ and the $A$ and B treatments.

Treatments A, B and C were judged slightly hard, while sample $E$ with $50 \%$ chocolate content was found significantly better in terms of hardness. The result was similar in the case of moisture content. The A-D samples were slightly/moderately dry, while treatment $E$ was nearly neutral or slightly soft and friable (Figure 2). 


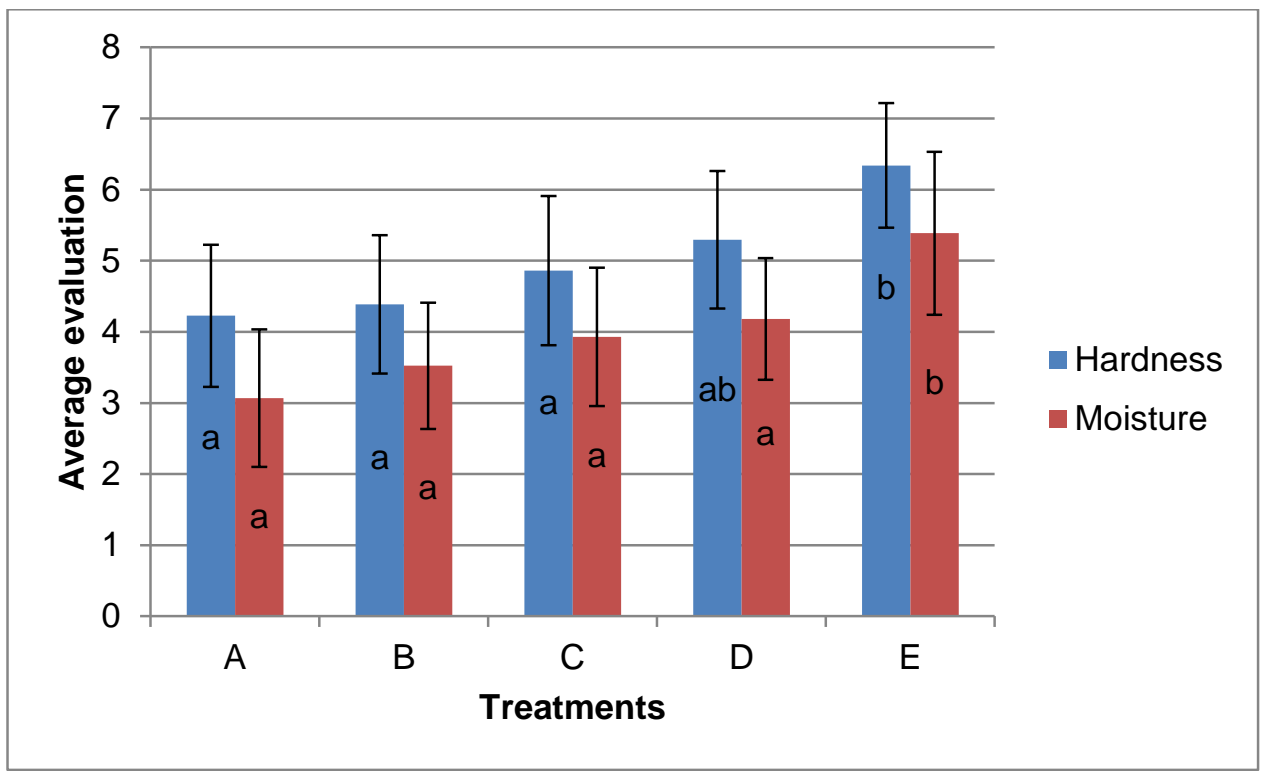

Figure 2. Evaluation the hardness and moisture of biscuits made from oak acorn meal

In the examination of the odor, it can be stated that negative experience was not observed by the tasters. All five treatments received a higher than five, slightly/moderately pleasant evaluation. At the same time, the statistically significant difference can also be observed between $A-C$ and $E$ treatments.

In the case of after taste there was the highest difference between $A$ and $E$ treatments (almost 4 points). The tasters had a clearly negative opinion when evaluating the after taste of A-D samples. The differences can be observed not only between the ends of the scale, but also between side by side treatments. This is the only parameter of the five examined aspects, which values divided the pairwise comparison into three groups by the 44 tasters. By increasing the amount of the chocolate content, the difference between treatments has also increased (Figure 3).

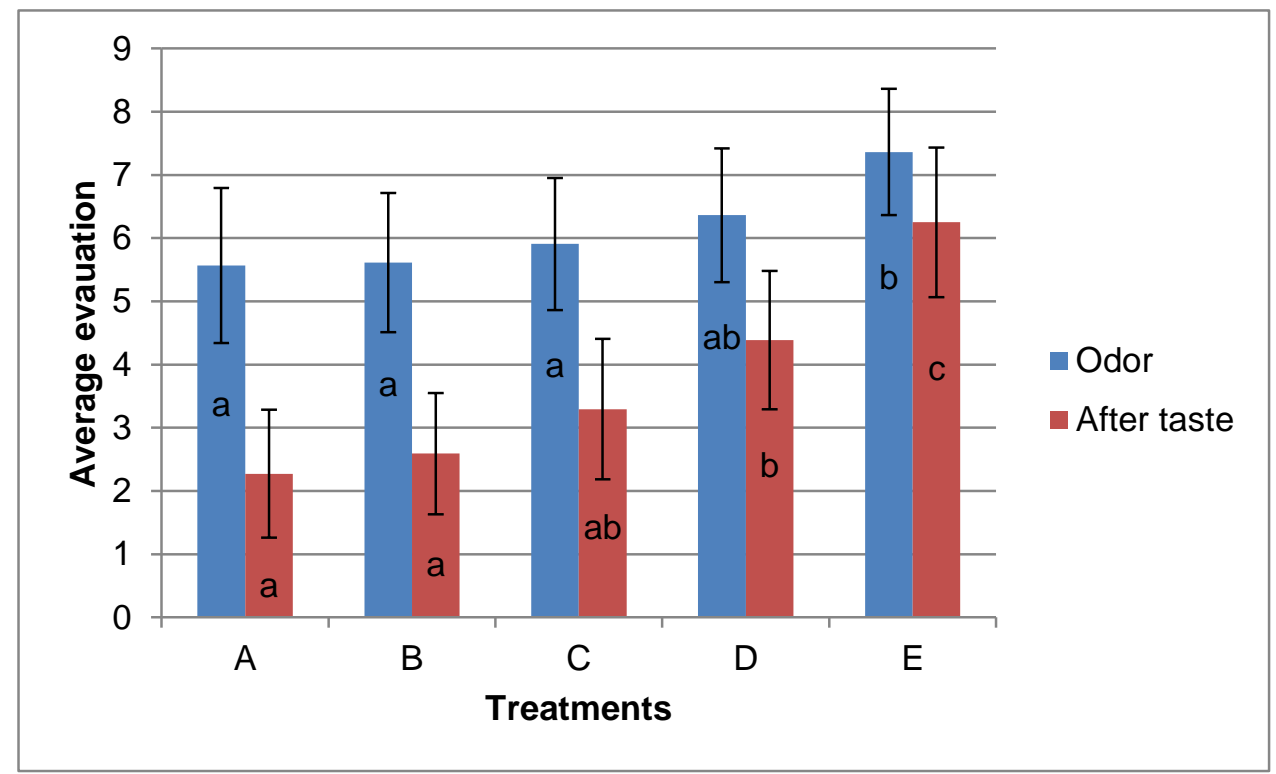

Figure 3. Evaluation the odor and after taste of biscuits made from oak acorn meal

The detailed examination of the data, it is conspicuous that treatment with the lowest chocolate content did not receive a score higher than 5 . At the same time there were three tasters who gave 8 points for these two samples, but the mean value of these was below 3 . The other 
extremity is the two tasters, who also experienced a very bitter taste in the $50 \%$ chocolate content E treatment.

Although we did not find significant differences between the sexes, we examined the opinion of women and men separately in the case of after taste. Approximately $60 \%$ of the 21 women and 23 men stated very negatively with treatment $A$ (value 1 ). Treatment $D$ was evaluated as neutral by $26 \%$ of men but $9.5 \%$ of women. $64 \%$ of the under the age of 30 said the treatment $A$ was very bitter (1), while $50 \%$ of the over 30 group stated the same. Those who felt treatment $D$ and $E$ unpleasant were also among the younger tasters, while $18.75 \%$ of older tasters evaluated treatment A 8 points. There was no statistical difference between age and educational level.

\section{Conclusions}

Based on the results, it can be stated that $E$ treatment with $50 \%$ chocolate content is significantly better for all parameters compared to the A and B samples. The produced biscuits have slightly dark or neutral color and their scents were evaluated pleasant. The tasters found the hardness more or less neutral, but the moisture content of the biscuits must be increased. It should be highlighted, that the 6.25 mean points of after taste of $E$ treatment is far below the maximum ( 9 points for this sample was evaluated by only 10 tasters). Because of this, other solutions (for example almond flour, peanut cream, etc.) are needed to make this functional food raw material in addition to its health care role, it is also suitable for consumption.

\section{Acknowledgment}

Thank you for the support of the research carried out in the framework of the EFOP-3.6.2-162017-00012 „Developing a functional, healthy and safe food product chain model from field to table in a thematic research network". The project is funded by the Hungarian State and the European Union, co-financed by the European Social Fund, and is part of the Széchenyi 2020 program.

\section{References}

[1] Chung, K.-T., Wong, T. Y., Wei, C-I., Huang, Y.-W. and Lin, Y. (1998): Tannins and Human Health: A Review. Critical Reviews in Food Science and Nutrition. 38(6): 421-464. https://doi.org/10.1080/10408699891274273 [Accessed: 10-Nov-2018]

[2] Dénes A. - Papp N. - Babai D. - Czúcz B. - Molnár ZS. (2013): Ehető, vadon termő növények és felhasználásuk a Kárpát-medencében élő magyarok körében néprajzi és etnobotanikai kutatások alapján. Dunántúli Dolgozatok $(A)$ Természettudományi Sorozat. 13:35-76.

https://www.researchgate.net/publication/274509573 Eheto vadon termo novenyek es felhasznalasuk a Karpat medenceben elo magyarok koreben neprajzi es etnobotanikai kutatasok alapjan/link/5521337a0cf29dcabb0b8 7c9/download [Accessed: 6-Apr-2017]

[3] KAROLYI, D., SALAJPAL, K., KIŠ, G., DIKIĆ, M., JURIĆ, I. (2007): Influence of finishing diet on fatty acid profile of longissimus muscle of black slavonian pigs. Agriculture 13 (1): 176-179.

[4] Kilic, U., Boga, M., Guven, I. (2010): Chemical Composition and Nutritive Value of Oak (Quercus robur) Nut and Leaves. Journal of Applied Animal Research. 38:101-104. https://www.researchgate.net/publication/236969129 Chemical Composition and Nutritive Value of Oak Querc us robur Nut and Leaves [Accessed: 28-Nov-2019]

[5] LEON-CAMACHO, M., VIERA-ALCAIDE, I., and VICARIO, I. M. (2004): Acorn (Quercus spp.) fruit lipids: saponifiable and unsaponifiable fractions: a detailed study. Journal of American Oil Chemists Society. 81: 447-453. https://www.researchgate.net/publication/225901800 Acorn Quercus spp fruit lipids Saponifiable and unsaponi fiable fractions A detailed study [Accessed: 28-Nov-2019]

[6] LOPES, I. M. G., BERNARDO-GIL, M. G. (2005): Characterisation of acorn oils extracted by hexane and by supercritical carbon dioxide. European Journal of Lipid Science and Technology. 107: 12-19. https://www.researchgate.net/publication/230210359 Characterisation of acorn oils extracted by hexane and b y supercritical carbon dioxide [Accessed: 28-Nov-2019]

[7] NIKOLIĆ, N., ORLOVIĆ, S., KRSTIĆ, B., KEVREŠAN, Ž. (2006): Variability of acorn nutrient concentrations in pedunculate oak (Quercus robur L.) genotypes. Journal of Forest Science 52 (2): 51-60. https://www.agriculturejournals.cz/publicFiles/55076.pdf [Accessed: 28-Nov-2019]

[8] ÖZCAN, T. (2006): Total Protein and Amino acid Compositions in the Acorns of Turkish Quercus L. Taxa. Genetic Resources and Crop Evolution 53 (2): 419-429. https://link.springer.com/article/10.1007/s10722-004-1337-7 [Accessed: 28-Nov-2019]

[9] PALADA-NICOLAU, M., HAUSMAN, J. F. (2001): Comparison between somatic and zygotic embryo development in Quercus robur L. Plant Biosystems 135: 47-55. https://www.tandfonline.com/doi/full/10.1080/11263500112331350640 [Accessed: 28-Nov-2019] 
[10] PETROVIC, S., SOBAJIC, S., RAKIC, S., TOMIC, A., and KUKIC, J. (2004): Investigation of kernel oils of Quercus robur and Quercus cerris. Chemistry of Natural Compounds. 40: 420-422.

https://link.springer.com/article/10.1007/s10600-005-0003-4 [Accessed: 28-Nov-2019]

[11] Pozsgainé H. M. (2008): Abiotikus hatások kémiai vizsgálata a kocsányos tölgy (Quercus robur L.) makk tárolása és korai ontogenezise folyamán. Doktori disszertáció. Nyugat-magyarországi Egyetem Erdőmérnöki Kar, Sopron. http://doktori.nyme.hu/27/1/disszertacio.pdf [Accessed: 28-nov-2019]

[12] RAKIĆ, S., POVRENOVIĆ, D., TEŠEVIĆ V., SIMIĆ, M., MALETIĆ, R. (2006): Oak acorn, polyphenols and antioxidant activity in functional food. Journal of Food Engineering. 74: 416-423. https://www.sciencedirect.com/science/article/abs/pii/S0260877405001810 [Accessed: 28-nov-2019]

[13] SALAJPAL, K., KAROLYI, D., BECK, R., KIŠ, G., VICKOVIĆ, I., DIKIĆ, M. and KOVAČIĆ, D. (2004): Effect of acorn (Quercus robur) intake on faecal egg count in outdoor reared black slavonian pig. Acta Agriculturae Slovenica 1: 173-178.

https://www.researchgate.net/publication/285389432 Effect of acorn Quercus robur intake on faecal egg coun $\underline{t}$ in outdoor reared black Slavonian pig [Accessed: 28-nov-2019] 